\title{
Consumers' perception of the complexity of selected household purchase decisions
}

Alet C. Erasmus ${ }^{\mathrm{a} *}$, Sune Donoghue ${ }^{\mathrm{a}}$, Thomas Dobbelstein ${ }^{\mathrm{b}}$

${ }^{a}$ Department of Consumer Science, University of Pretoria, 0002, South Africa

${ }^{\mathrm{b}}$ Duale Hochschule Baden-Württemberg,Rudolfstraße 11, 88212 Ravensburg, Germany

\author{
Alet C Erasmus \\ University of Pretoria \\ Department of Consumer Science \\ South Africa \\ alet.erasmus@up.a.za
}

Sune Donoghue

University of Pretoria

Department of Consumer Science

South Africa

sune.donoghue@up.a.za

Thomas Dobbelstein

Duale Hochschule Baden-Württemberg

Rudolfstraße 11, 88212 Ravensburg, Germany

dobbelstein@dhbw-ravensburg.de

*Corresponding author: Tel +27 12420 2575, fax: +27 124202855

E-mail address: alet.erasmus@up.a.za (A. C. Erasmus) 


\section{Consumers' perception of the complexity of selected household purchase decisions}

\section{ABSTRACT}

This study provides evidence of consumers' perception of the complexity of a variety of product/service decisions in terms of a complexity continuum and indicates how such categorization is influenced by specific demographic characteristics, specifically gender, age and education level that are predominant in terms of consumer socialisation. A survey which was conducted in a major city and involved 461 respondents. The multiple section structured questionnaire were completed by willing spouses/partners of participating households. Complexity values were calculated in terms of a specific anchoring product, namely major household appliances. It became evident that the most expensive purchases that households ever make, namely purchasing a home and a car, which were perceived to be the most complex by all while grocery purchases was on the least complex divide of the continuum. Also on the more complex divide of the continuum were service related decisions such as insurance. Particularly noteworthy is the confirmation of significant differences in perceived complexity within product categories that are perceived to be the most- and the least complex by all. This confirms the vulnerability of certain segments of the consumer society and the need for concerted effort to communicate with them in appropriate media and on a level that would enhance informed consumer decision-making. Underlying reasons probably relate to consumers' risk perception and affordability issues that could be explored in future research. Interestingly the findings of the gender comparison shifted the focus to different product categories than those elicited in the age-, income and level of education comparisons. Findings therefore confirm the relevance of demographic characteristics in media communication and consumer facilitation as well as in research. Retailers and marketers should therefore be cognisant of the characteristics of their target markets and be very selective and cautious when identifying communication media. $<300$ words

This study provides evidence of consumers' perception of the complexity of a variety of product/service decisions in terms of a complexity continuum and indicates how such a categorization is influenced by specific demographic characteristics, specifically gender, age and education level that are predominant in terms of consumer socialisation. A cross-sectional survey was conducted and 461 useful questionnaires were collected. Complexity values were calculated in terms of a specific anchoring product, namely major household appliances. Particularly noteworthy is the confirmation of significant differences in the perceived complexity within the most and least complex product 
categories. Gender comparisons indicated to different product categories than those concerning the age, income and level of education comparisons. $<100$ words

\section{Key words}

Complex purchase decisions; Consumer decision-making; Gender; Demographic influences; Complexity continuum 


\section{Introduction}

Without exception, consumer behaviour research always has consumer decision-making at its core and over time scholars have made considerable effort to explain the dimensions of consumer decision-making. Sproles and Kendall (1986) for example aimed to understand consumer decision-making in terms of consumers' decisionmaking styles to find some common ground whereby theorists, educationists and marketers could make some valid assumptions and predictions about consumers' choices across a range of product categories. These authors' main concern was that the abundance of previous work is based on marketing-business needs while the consumer interest was mostly neglected. During the same time Puto (1987) published an award winning article which drew scholars' attention to context effects on consumers' value judgements and how they use standards of comparison to frame buying decisions in terms of gains and losses. Acknowledging the valuable contribution of Kahnemen and Tversky (1979) that showed that decision frames can be used as reliable predictors of risky choices, the author cautioned that it is however not clear how these reference points and decision frames are established in individual purchase situations. Based on prospect theory he eventually concluded that buying decisions are "edited" as the decision process progresses because consumers are influenced by contextual cues. In another attempt (Sheth et al, 1991) that involved an extensive range of consumer products that included durable, non-durables, industrial goods as well as services, the complexity of purchase decisions was investigated in terms of associated consumption values, once again proposing different outcomes for different contexts.

In terms of marketing and education, some simplification of consumer decisions is however needed to categorise products to exemplify differences among products and how that may influence consumers' perceptions and purchase decisions. This is evident from the way in which products are referred to in publications. Mostly, some continuum ranging from high involvement/extended- (which refers to decisions that require more attention and effort), to low involvement/routine decision-making (which is generally completed in limited time with limited cognitive and emotional strain), is improvised to explain some linear difference in the intricacy of dissimilar product decisions and to acknowledge the amount of time and effort as well as the information search required to explore the plethora of alternatives and to deal with the task complexity. Inevitably then, different decision strategies are used to deal with the purchase process (Swait and Adamowicz, 2001; Solomon, 2011, p.334). Consumers' purchase decisions are unavoidably influenced by the individual's experience in a specific product category and the time lapse since the

4 | P a g e 
previous purchase that will determine the effort made to evaluate product alternatives (Winer, 1986). When making choices under uncertainty, consumers would typically try to minimise losses and to maximise gains. In doing so, the outcome of a risky decision is generally evaluated in terms of a value function where gains and losses are defined in terms of a reference point, loss aversion and diminishing sensitivity. A consumer's perception of the loss of a utility, i.e. forfeiture if the product fails expectations, apparently often exceeds the utility gain under optimal conditions. For example, when a service provider fails to provide the expected service, the loss incurred may seem more extensive than the gains obtained under conditions when the service is performed to perfection (Tversky and Kahneman, 1991). Depending on the product category, a consumer's decision strategy is further directed by utilitarian and hedonic considerations. Certain products are primarily utilitarian, i.e. decisions are mostly cognitively driven, instrumental and goal directed while others are hedonic and driven by excitement, pleasure, fantasy and fun, for example when purchasing tickets for a theatre, or choosing a ball gown. The purpose of the purchase therefore determines the strategy used to identify the most suitable product (Dhar and Wertenbroch, 2000).

Scholars therefore concur that an element of anxiety or risk perception is involved in every consumer decision and that the context can aggravate the complexity (Williams and Noyes, 2007; Mandlet al., 2011; Hoyer et al., 2013, p.59; Weber and Hsee, 1998). It is an almost axiomatic conclusion that the more complex a purchase decision, the more extensive and time consuming the information search that would enable an informed purchase decision and to reduce consumers' risk perception. Keller and Staelin (1987) however propose that the complexity of an intricate consumer decision may have an inverted $\mathrm{U}$-shaped relationship with decision efficiency. They propose that as decisions become more complex, consumers initially make considerable effort to solve the problem and become increasingly more efficient in reaching an informed purchase decision. A point is however reached where the effectiveness of a consumer decision begins to decline for various reasons, e.g. the decision is too complex, lack of processing capacity because the information is beyond comprehension, dysfunctional search, frustration due to information overload, and even time constraints that limit the investigation (Sproles and Sproles, 1990; Ursic and Helgeson, 1990; Grant et al., 2010). Purchase decisions that are perceived to be highly complex may therefore be particularly challenging and even cause consumers to defer choice at some point by choosing what they are familiar with, or to avoid choice (Dhar, 1997; Mandl et al., 2011).While this does not reflect informed consumer decisionmaking and may result in dismay and even consumer dissatisfaction, consumers' hesitance may also cause retailers and brands to suffer extensive financial losses. When explaining task complexity and related decision strategies, 
Swait and Adamowicz (2001) for example indicate that consumers may adopt simplification procedures to cope with complex purchase decisions, such as ignoring attributes that seem less important to them, or by ignoring magnitudes and giving directional equal importance to all attributes. When introducing a new product with novel features, a supplier's inventiveness may therefore be negated if consumers fail to prioritise new attributes and to align the new product features with their own product needs.

On a macro level, i.e. in terms of their marketing initiatives, retailers have little interest in individual consumers' choice decisions. Rather, retailers wish to understand consumer decision-making from a heterogeneous viewpoint in order to offer the range of products and support systems that would target a broader target market to maximise their profits (Shao et al., 2009). A generalised confirmation of the complexity of purchase decisions in terms of coherent product categories would therefore be valuable to retailers and marketers in several ways. It would aid in understanding consumers' pre-purchase anxiety and to associate consumers' risk perception with merchandise that are similar in complexity so that consumer facilitation processes could be structured more purposefully. This would enhance an understanding of the challenges that consumers are faced with, i.e. how their purchase decisions are framed before they commence their pre- purchase enquiries and to ensure that their store visits are worthwhile. At the same time, advertising budgets of marketing managers could be allocated with more certainty if they know what type of information is required by which market segments.

\section{Aim of the study}

This study aims to expand consumer decision-making literature through empirical evidence presented in terms of a complexity continuum that depicts consumers' perception of the complexity of a variety of product/service decisions that households deal with from time to time. Although the investigation admits the potential influence of various individual- and context related factors on an individual's perception of the complexity of a specific purchase decision, this investigation does not focus on the complexity of the decision process. It merely aims to provide a broad categorisation of products and services that are perceived to be similar in complexity to instigate further research that could extend the details of the investigation and to provide guidelines for marketing managers and retailers who need to design their marketing mix in accordance with the profile, needs and perceptions of their consumer markets to optimise their resources and to increase their competitiveness. It hence also aims to indicate 
how such a categorisation is influenced by consumers' demographic characteristics that are predominant in terms of consumer socialisation, i.e. gender, age and education level

\section{Problem statement}

Ample evidence confirms the relevance of product related consumer socialisation in terms of the perceived complexity of a specific purchase decision based on the rich source of information gained by previous experiences which boosts one's cognitive ability to comprehend and to identify relevant product attributes during a challenging purchase decision (Sproles and Sproles, 1990; John, 1999; Watson and Spence, 2007. Dellaert et al., 2008). Perceived complexity influences perceived risk and measures taken to overcome the anxiety(Weber and Hsee, 1998; Mandl et al., 2011). The same product would therefore not necessarily entail the same level of complexity or pose the same level or type of risk for every consumer (Sproles and Sproles, 1990; Ratneshwar et al., 1997; Lindquist and Sirgy, 2006; Weber and Johnson, 2006; Babin and Harris, 2011, p.218). Intricate measures such as those used in information theory have been used in the past to quantify the complexity of specific purchase decisions and related entropy, i.e. the amount of uncertainty involved (Swait and Adamowicz, 2001). To date, however, when explaining consumer decisions in literature, authors generally still arbitrarily provide examples of products and services that presumably differ in complexity to distinguish different types of consumer decisions as limited empirical evidence exists to categorically distinguish and tie a level of complexity to specific product- or service categories. In an attempt of Iacobucci (1992) to distinguish the complexity of selected purchase decisions, the focus was to conceptualise tangible and non tangible goods and to distinguish the complexity of tangible and intangible products. Although this investigation produced invaluable findings, namely that information used to purchase tangible products are more search based, while information used to purchase intangibles are more experience based, the author concluded that the article was a "fun read" and that the topic should be explored further. This research was therefore not conclusive. It is hoped that a founded categorisation of the complexity of purchase decisions would instigate more extensive research that would exemplify in more depth the complexity of specific decision categories in terms of context specific scenarios.

\section{Conceptual background}




\subsection{Different consumer decisions}

The ideal outcome of a consumer decision is confirmation of a consumer's expectations, which triggers consumer satisfaction (Swait and Adamowicz, 2001; Hawkins and Mothersbaugh, 2010, p.634). Purchase decisions are however seldom straightforward and differ from one person to the next and from one product to another (Ursic and Helgeson, 1990; Dellaert et al., 2008). Literature generally distinguishes extended (complex), limited, and habitual (routine) decision-making (Hawkins and Mothersbaugh, 2010, p.498; Jobber, 2010, p.123; Mandl et al., 011). Complex purchase decisions typically require more extensive deliberation during the decision process for whatever reason such as higher prices, the intricacy of the product's performance or its social visibility and therefore the decision can not be rushed or concluded without additional information that would support the final decision and reduce the possibility of a negative post purchase outcome. A purchase decision is eventually influenced by multiple factors that contribute to a consumer's risk perception, specifically the type of risk and how the risk is eventually dealt with and resolved. Gronhaug et al. (1987) for example operationalise major household decisions in terms of the fraction of the budget available for the purchase, which severely limits their discussion of the complexity to financial risk.

Complex decision-making generally requires higher personal involvement and implies a significant amount of risk. Choosing expensive, visually significant products and products with complex features generally requires higher cognitive effort and when the functional utility of a product is predominant, decisions may be more rational and deliberated (Bettman et al., 1998). For example, when purchasing a car or a home, a consumer mostly has many options to choose from, which may be overwhelming. Both these products however also require a consideration a multitude of attributes that have considerable cost implications. This explains why a home and a car is typically used by scholars to explain the complexity of purchase decisions (Chandrashekaran and Jagpal, 1995; Bettman et al., 1998). Similarly, service related decisions would be particularly complex due to their intangibility (Pérez-Cabañero, 2007; Keh and Sun, 2008; Schiffman and Kanuk, 2010, p.203) and difficulty to anticipate what one is actually paying for (Jordaan and Prinsloo, 2004, p.13). Compared to a home, a car, a washing machine and a hair dryer, it is much more difficult to evaluate a service for example life insurance because it might take quite some time to experience actual evidence of their service offering. Consumers may furthermore struggle due to limited processing 
capacity, for example lower educated consumers (Bettman et al., 1998) or young and inexperienced consumers who lack relevant product knowledge and related experience to evaluate product alternatives rationally (John, 1999; Jobber, 2010, p. 123). They would typically then construct their product preferences on the spot in the store, or apply decision strategies, for example relying on price or the brand as an indication of trustworthiness (Bettman, et al., 1998). They may also seek supporting information from the Internet or significant others (Koch et al., 2008; Parumasur and Roberts-Lombard, 2012, p.258), which could result in a frustrating, fairly time consuming endeavour (Hawkins and Mothersbaugh, 2010, p.533). The contrary is true for cheaper products and products with simple features (Sridhar, 2007). Various avenues can be pursued to reduce perceived risk, for example to involve trusted others such as friends, significant others and experts for assistance and to search for information in written format or on-line (Henthorne et al., 1997; Brown and Venkatesh, 2005; Doole et al., 2005, p.34; Grant et al., 2010; Hawkins and Mothersbaugh, 2010, p.533).

Various factors may induce concern and anxiety during the decision-making process, for example when uncertainty about the suitability of a specific product/service arises, due to lack of confidence that would support the purchase decision and if the possibility exists that a product/service may not meet one's expectations or the approval of your social group (Ursic and Helgeson, 1990; Swait and Adamowicz, 2001; Dellaert et al., 2008). The duration and extent of the decision-making process is therefore eventually largely determined by the product type and price, the situation, the consumer's risk perception as well as the individual's approach to the decision process, i.e. an economic, rational, blasé, passive, an emotional or cognitive approach (Chandrashekaran and Jagpal, 1995; Mandel, 2003; Hawkins and Mothersbaugh, 2010, p.536; Kardes et al., 2011, p.64; Mandlet al., 2011; Parumasur and Roberts-Lombard, 2012, p.259).The following hypotheses are therefore formulated in terms of the relative position of purchase decisions on a complexity continuum:

H1: The more expensive a product, for example home and a car, the higher the perceived complexity of the purchase decision.

H2: Purchase decisions that involve intangible characteristic, for example services are high in complexity.

H3: Purchase decisions that are made less frequently, for example a home and a car, are high in complexity.

H4: Purchase decisions with social implications, for example a home, a car, and clothing, are high in complexity.

H5: Purchase decisions that involve an evaluation of technological features, for example electronics, are high in complexity. 
Limited decision-making refers to purchase decisions that imply some form of risk and where limited information is required to assess alternatives and to prevent a wrong decision (Doole et al., 2005, p.35; Peter and Olson, 2010, p.74-75, 174; Kardes et al., 2011, p.64). With prolonged experience many purchase decisions become habitual or repetitive simply because consumers have become familiar with the attributes, benefits and the perceived value of the products (Peter and Olson, 2010, p.70; Mandl et al., 2011), for example a person that generally purchases groceries for their household may find the task easy while a young couple who are starting up their home may disagree. Eventually, purchase decisions are easy to conclude when it does not involve lots of money, when it is easy to identify a suitable alternative and when the purchase decision poses little doubt, harm or loss, and the probability of a wrong purchase decision is small. Habitual (routine) purchases are mostly lower priced, frequently purchased products that pose limited risk and which may even instigate inertia or a disinterest in alternative products. Consumers seldom engage in extensive evaluation processes for routine purchases because the relative cost in terms of time and energy spent is not worthwhile (Mandl et al., 2011; Parumasur and Roberts-Lombard, 2012, p.257). The following hypothesis is therefore proposed:

H6: Routine purchases, for example grocery purchases, are low in complexity.

\subsection{Cognitive processes involved in consumer decision-making}

A consumer's cognitive involvement during a purchase decision depends on how complex the purchase decision is perceived to be. Generally, the more complex a purchase decision, the higher an individual's cognitive involvement and the more extensive the rational deliberation (Bauer et al., 2006; Dellaert et al., 2008; Hawkins and Mothersbaugh, 2010, p.554). A better educated consumer would therefore be better equipped to search and use product related information to reduce risk perception (Hawkins and Mothersbaugh, 2010, p.253, 536). Consumers who are less experienced for whatever reason, for example young consumers, those with lower education levels, or individuals who have limited experience in a particular product category, may find certain consumer decisions more challenging. The contrary is however true for individuals who possess the cognitive ability to comprehend and interpret intricate product cues. Over time, a consumer also develops pertinent and established beliefs about certain brands and products that are framed in terms of what a consumer is accustomed to, a consumer's personal needs 
and/or requirements (Mandl et al., 2011). Purchase decisions that are generally performed by males may therefore seem more complex for females and visa versa. The following directional hypotheses are therefore proposed:

H7: A gender comparison of consumers' perception of the complexity of purchase decisions reveals that: H7.1: The complexity of purchase decisions that are attribute-based is higher for females compared to males.

H7.2: The complexity of purchase decisions that lack tangible requisites is significantly higher for males compared to females.

H8: The complexity of purchase decisions is higher for consumers with limited experience, such as:

H8.1 younger consumers

H8.2 consumers who are unfamiliar with a specific purchasing task

H9: The complexity associated with purchase decisions is higher for consumers with lower education levels.

Because individuals with lower education levels generally also have lower paid jobs, it is also hypothesised that:

H10: The complexity associated with purchase decisions is higher for consumers with lower income levels.

\section{Methodology}

A quantitative survey was undertaken in a major urban area in South Africa in 2012. A multiple section, structured questionnaire was designed to gather demographic information, to investigate the complexity of selected purchase decisions relative to an anchoring product which served as reference point, and to investigate consumers' risk perception when confronted with a selection of products and services that households would be familiar with. Items for the latter section were derived through an iterative process during which 18 fourth year Consumer Science students were tasked to compile a list of products and services that differed in complexity based on their construal of existing literature. Students' lists were integrated, duplications were eliminated during panel discussions and the remaining items were reduced to 16 coherent categories (e.g. furniture, electronics) that included products and services for the investigation. The final questionnaire was scrutinised by a statistician and then pre-tested with twenty subjects who fit the requisites for the study to eliminate error.

Eighteen trained field workers recruited respondents by means of convenience sampling. They were assigned to specific suburbs across the city and each had to distribute a specific number of questionnaires on a drop-off-collectlater basis in accordance with a sampling plan which aimed to involve a proportional representation of consumers from middle- to upper socio-economic backgrounds as per the demographic profile of the area. The 500 questionnaires were handed out for self completion to willing individuals above 21 years of age, irrespective of 
gender and their population affiliation after an explanation of the purpose of the study. Completed questionnaires were sealed in envelopes by the respondents before returning them to ensure anonymity as explained during the introductory meeting. Questionnaires were collected per appointment after three days. It was hence not clear which of the partners in the household had completed the questionnaires, which unfortunately meant that the researchers had no control over the gender representation in the sample although men were encouraged to participate. No pressure was exerted if respondents failed to complete the questionnaire in time. Within three weeks, 461 useable questionnaires were retrieved. Data were coded by the same field workers under supervision of the researchers and the captured data were cross-checked to correct errors before data analysis commenced.

The gender representation in the sample was coincidental as questionnaires were completed by any willing partner or spouse in participating households. Although males were encouraged to participate, no pressure was exerted. The majority of the respondents $(N=461)$ were females $(n=327 / 70.9 \%$; males: $n=134 / 29.1 \%)$. A previous study that was done in the same geographic area (Sonnenberg et al., 2011) concluded that purchase decisions in this product category are mostly female driven although more than $40 \%$ of households engaged in joint decision-making.

Age information (continuous data) was converted to four categories to discriminate younger consumers with limited experience ( 21 to <30 years of age: $\mathrm{n}=139 / 30.4 \%$ ); those who have probably purchased more than one major appliance over time (30 to $\leq 40$ years: $\mathrm{n}=104 / 22.7 \%$ ); consumers who have most likely made at least one replacement purchase in this product category ( 40 to $\leq 49$ years: $n=95 / 20.7 \%$ ) and older consumers who would probably be more experienced compared to younger consumers based on more extensive purchase experience over time $(\geq 50$ years: $\mathrm{n}=120 / 26.2 \%)$.

Although household income level categories were specified in the questionnaire to reduce possible intimidation when requested to provide precise household income figures in an open ended question, $3.04 \%$ of the respondents nevertheless withheld the information. Income categories were regrouped for further analysis in accordance with the most recent population report of the city (City of Tshwane Survey, 2008), namely R5K to <R15K: n = 149/40.04\%; $\geq \mathrm{R} 15 \mathrm{~K}$ to $<\mathrm{R} 25 \mathrm{~K}: \mathrm{n}=107 / 23.94 \%$; $\geq \mathrm{R} 25 \mathrm{~K}: \mathrm{n}=161,36.02 \%$ (Currency: $1 \$ \simeq 10 \mathrm{ZAR}$ ).

Three education levels (categorical data) were distinguished, namely those who did not progress further than secondary schooling ( $\leq$ Grade $12: \mathrm{n}=136 / 29.96 \%)$; individuals who completed a diploma or degree post their secondary school certificate $(n=210 / 46.26 \%)$, and those with a post graduate qualification: $n=108 / 23.79 \%)$. 


\subsection{Measures and analyses}

The parameters for consumers' judgement of the complexity of the selected purchase decisions were set in terms of an anchoring product to ensure a similar point of departure for all evaluations. The aim was to infer, on a horizontal continuum, products/services that consumers generally perceive as more complex and less complex than the anchoring product. A washing machine as an example of a major household appliance (MHA) that most households own, was specified as the anchoring product for the investigation based on evidence that is fairly challenging to purchase MHA (Donoghue et al., 2008; Sonnenberg et al., 2011) due to the multiple forms of risk that is associated with such purchase decision across most consumer segments (Nieftagodien and Van der Berg, 2007). It was presumed that the procedure would allow for a distribution of purchase decisions on either side of MHA on an envisaged complexity continuum. Respondents distinguished the complexity of every purchase decision relative to the anchoring product (which served as reference point) by means of two questions on a four point Likert-type agreement scale. They firstly indicated how much more complex it would be to purchase the selected products and services compared to purchasing MHA. To verify their responses, respondents subsequently completed the task in reverse, i.e. indicating how much less complex they regarded the same purchase decisions compared to purchasing MHA.

During the initial descriptive analysis of the data the four increment Likert-type scale was collapsed by combining the mostly and always responses, and the sometimes and never responses as positive and negative judgements respectively. A complexity value was subsequently calculated for each of the listed products and services by subtracting the scores for the two separate complexity judgements for each respondent. An individual's responses to the question "How much less complex do you consider each of the listed products and services compared to purchasing a major household appliance such as a washing machine" were subtracted from the reverse formulation, i.e. "How much more complex ..." to demarcate the parameters for the highest and lowest possible complexity values for each product/service, namely:

Highest complexity value: [Q $\mathrm{Q}_{\text {Most complex }} 4$ (always) minus $\mathrm{Q}_{\text {Less complex }}: 1$ (never) $\left.=3\right]$

Lowest complexity value: [ $\mathrm{Q}_{\text {Most complex }}: 1$ (never) minus $\mathrm{Q}_{\text {Less complex }}: 4$ (always) = -3]

Products/services were then ranked from the least- to the most complex purchase decision relative to purchasing MHA and significant differences in the complexity perceptions within demographic categories were distinguished 
through t-tests (to compare two sets of data, for example gender) and one way interdependent ANOVA where three or more demographic categories were present.

\section{Results}

Findings for the two questions where respondents were compelled to consider the complexity of the purchase decisions in the reverse are visually presented in Figure 1 with the anchoring product positioned at the 50/50 interval distinguishing products/services considered mostly/ always more complex and products/services considered mostly/always less complex than purchasing MHA. The near identical opposite graphs confirm the consistency of the data.

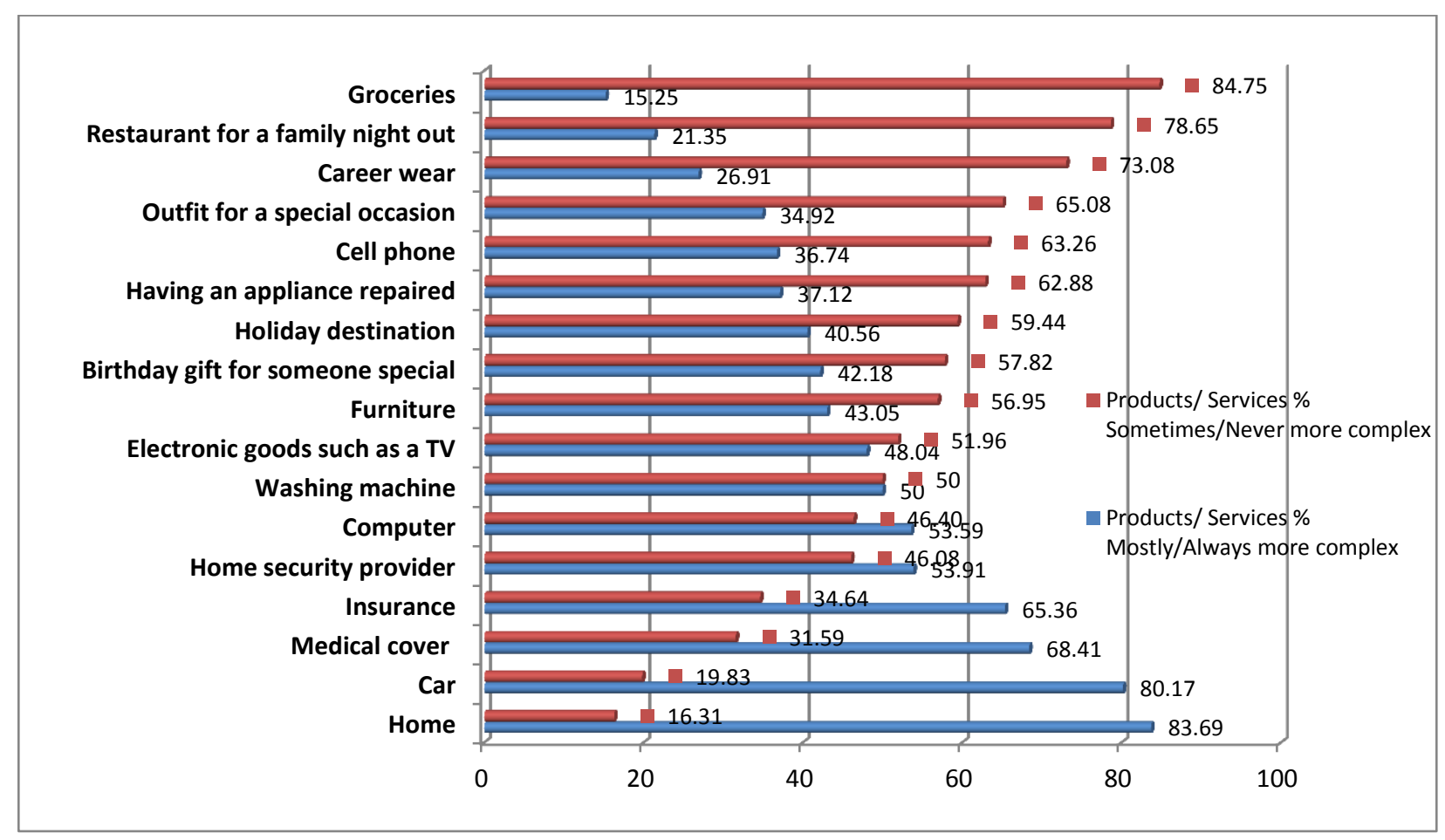

\section{Figure 1.}

A two tier presentation of consumers' perception of the complexity of purchase decisions 
More than $80 \%$ of the respondents regarded purchasing a home and purchasing a car, which represent purchases with considerable financial and social implications (Mandel, 2003; Hawkins and Mothersbaugh, 2010, p.536; Schiffman and Kanuk, 2010, p.316), as much more complex than purchasing MHA. Other purchase decisions which implied substantial complexity relative to the anchoring purchase decision were predominantly service related, i.e. choosing medical cover, purchasing insurance, as well as choosing a home security provider. The complexity of service related decisions can be attributed to their intangibility (Iacobucci, 1992; Pérez-Cabañero, 2007;Keh and Sun, 2008) and difficulty to anticipate what one is actually paying for (Jordaan and Prinsloo, 2004, p.13).The contrary is true for cheaper products and products with simple features (Sridhar, 2007, p. 133). Not surprisingly therefore, more than $70 \%$ of the sample indicated that purchasing groceries (a typical routine purchase) and choosing a restaurant for a family night out are always/mostly easier to purchase than the anchoring product. The restaurant scenario differs from a meal with friends where social influences (amongst others) may complicate consumers' choices.

The complexity ranking for the products is presented in Table 1 , which also lists the 16 products and services included in the study. Products range from the least complex- $\left(\mathrm{M}_{\text {Groceries }}=-1.48\right)$ to the most complex purchase decision $\left(\mathrm{M}_{\text {Home }}=1.83\right)$ relative to purchasing MHA. The maximum and minimum complexity values suggest that the products listed did not include the most- $(\mathrm{M}=+3)$ and least complex $(\mathrm{M}=-3)$ purchase decisions that households encounter from time to time and that the research could be extended to expand the product list. Purchasing groceries and choosing a restaurant for a family night out were the least complex of the purchase decisions compared to purchasing MHA. T-tests (i.e. the individual comparison of each of these purchase decisions to purchasing MHA, the reference product) revealed that these two product decisions with inclusion of both of the clothing purchases, purchasing a cell phone, having appliances repaired and purchasing a gift for someone special were regarded significantly less complex $(\mathrm{p} \leq 0.05)$ compared to purchasing MHA.

To conclude, purchase decisions that seem significantly more complex $(\mathrm{p} \leq 0.05)$ than purchasing the anchoring product, are purchasing a computer, choosing most of the intangibles that were service related, namely choosing $a$ home security provider and medical cover, as well as the two most expensive purchases that households generally make over time, namely purchasing a car and a home. Similar in complexity compared to purchasing MHA, are: choosing a holiday destination, purchasing electronic goods such as television sets, and purchasing furniture. Based 
on evidence that confirms the complexity of a MHA purchase decision, these decisions are therefore also complex, although not significantly more so than purchasing the anchoring product, and therefore they are flanked on a complexity continuum. These products form an integral part of the interior of a home and are equally important to display a family's lifestyle, which is indicative of stability and authority in the lives of the owners (Lihra and Graff, 2007 in Yoon et al., 2010; Chizinsky, 2010). They also represent the largest personal household consumption expenses that households encounter over time besides purchasing a home and car (Swanepoel, 2012).

Table 1 recapitulates the findings of the study in terms of the relative position of purchase decisions on a complexity continuum.

\section{INSERT TABLE 1 APPROXIMATELY HERE}

The influence of selected demographic characteristics on consumers' perception of the complexity purchase decisions provided valuable insights for retailers and marketing.

Gender: A T-test disclosed significant differences $(\mathrm{p} \leq 0.05)$ between males' and females' perception of the complexity of purchase decisions. Means as well as the outcomes of the Levene test are summarised in Table 3. Gender roles prescribe the appropriate behaviour of a consumer and influences a consumer's risk perception (Cant et al., 2006, p.94-95). In the context of this study men as well as women found it somewhat less complex to choose a repair service for MHA compared to the actual product purchase. Females, however, experienced the task significantly more complex than their male counterparts $\left(\mathrm{M}_{\mathrm{MComp}}=-0.44 ; \mathrm{M}_{\mathrm{F} \text { Comp }}=-0.12 ; \mathrm{p} \leq 0.05\right)$. Females' significantly higher complexity perception compared to males for a computer purchase $\left(\mathrm{M}_{\mathrm{MComp}}=-0.07 ; \mathrm{M}_{\mathrm{F} \text { Comp }}=\right.$ $+0.36 ; \mathrm{p} \leq 0.01)$ was expected, as males apparently process information more selectively and are inclined to rely on a limited amount of information and selected cues that are specific to their evaluations, which makes it easier to conclude a purchase decision. Females, in contrast, process information more comprehensively and tend to integrate multiple cues that may not even be crucial at the time (Wajda and Hu, 2004).Men are generally more confident than females and more willing to take risks compared to females who are inclined to perceive risky situations as a threat (Weber et al., 2002), which makes them more cautious. This is especially true for financial risks, which generally also prolong the decision process (Meier-Pesti and Goetze, 2006). Although both males $\left(\mathrm{M}_{\mathrm{MSec}}=+0,05\right)$ and females $\left(\mathrm{M}_{\mathrm{FSec}}=+0,45\right)$ indicated that it is more complex to choose a home security provider compared to 
purchasing MHA, females' complexity perception seems significantly higher than that of males $(\mathrm{p} \leq 0.01)$.Possibly certain purchase decisions such as repair services and choosing home security are still associated with the stereotypical and traditional role related responsibility of a man. For males, purchasing a birthday gift for someone special is significantly more complex than for females $\left(\mathrm{M}_{\mathrm{M} \text { Bgift }}=+0,12 ; \mathrm{M}_{\mathrm{F} \text { Bgift }}=-0.32 ; \mathrm{p} \leq 0.01\right)$. Men and women apparently vary in their emotional response to uncertain situations and this difference results in dissimilarities in risk taking (Croson and Gneezy, 2009). Lack of tangible provisos for a gift purchase as well as the multiple dimensions associated with gift giving, namely social, personal as well as economical (financial) factors (Sherry, 1983) probably explains the findings.

INSERT TABLE 3 HEREAge: Buying a home (+1.83) seems more complex than purchasing MHA across all age groups although the perceived complexity is the highest for the youngest consumer category. Differences among age groups' perception of the complexity of a home purchase decision is highly significant $(\mathrm{p} \leq 0.01)$. Regression analysis confirmed a significant inverse relationship between age and the complexity value $(p \leq 0,000)$, therefore the older the consumer, the lower the perceived complexity or vice versa $\left(\beta=-0,170 ; R^{2}=0.027\right)$. According to literature, risk perception differs across age groups. More mature consumers for example tend to be more quality conscious because they are more experienced in this product category, they may be less concerned about the distance of the property from schools and other amenities that are crucial younger consumers who have children, which makes the purchase decision much easier. Neither are older consumers concerned about peer values any more because they have established their social identities and are less materialistic than younger consumers who are more concerned with social risk (Mandel, 2003; Simcock et al., 2006; Le Roux and Erasmus, 2011).

Similar to the former, all respondents perceived buying a car as a more complex purchase decision than purchasing MHA. The complexity value decreases progressively and significantly for older consumers $(\mathrm{p} \leq 0.01 ; \beta=$ $\left.-0.170 ; \mathrm{R}^{2}=0.02\right)$. A home as well as a car purchase implies a considerable financial investment over an extended period of time, which increases consumers' risk perception and subsequently the complexity of the endeavour. Apart from juggling practical and functional considerations, one's home and car are furthermore typified as products that are consumed conspicuously and which facilitate social affiliation as well as socio economic status in society (Hawkins and Mothersbaugh, 2010, p.138). More experienced consumers are more able to retrieve brands and product characteristics that are appropriate for a purchase decision of the kind (Cowley and Mitchell, 2003) while 
expensive products and products with complex features generally also require higher cognitive effort of young consumers who are not that experienced yet (Jobber, 2010, p. 123). This may explain why older consumers with more product related experience and who probably also earn more, might find both of these purchase decisions significantly less complex.

Choosing a holiday destination probably presented the best example of the influence and challenges associated with age and stage of the family life cycle during consumer decision-making as the youngest $-\left(\mathbf{M}_{\leq 2}\right.$ yrsHol $\left.=-0.38\right)$ and the oldest age categories $\left(\mathrm{M}_{>49 \mathrm{yr} H \mathrm{H}}=-0.2\right)$ probably do not have to consider young children and other dependents (yet/ anymore) in terms of the suitability of a holiday destination to the extent that consumers in die middle age category have to. Differences in complexity across the age groups were significant $(\mathrm{p}<0.05)$.

When referring to an outfit (clothing) for a special occasion, all age groups concurred that it is a less complex purchase decision compared to MHA. Perceived differences among the age groups were significant $(\mathrm{p}<0.05)$. The lowest complexity value for the youngest age group $\left(\mathrm{M}_{\leq 29 \mathrm{yrSOuff}}=-0.81\right)$ can probably be ascribed to variety seeking (Lamb et al., 2008, p. 73), and a larger discretionary income during that stage of the life cycle due to fewer long term financial commitments that older consumers have to deal with. Similarly there was consensus thatchoosing $a$ restaurant for a family meal is less complex than purchasing MHA. This purchase decision seems considerably less complex for the youngest consumers $\left(\mathrm{M}_{\leq 29 \mathrm{yrsRest}}=-1.42\right)$ compared to the middle- and oldest age groups $\left(\mathrm{M}_{>29}\right.$ 49yrsRest $\left.=-0.83 ; \mathrm{M}_{>49 \mathrm{yrsRest}}=-0.86\right)$ and differences among age groups is highly significant $(\mathrm{p}<0.01)$. Young consumers generally have a larger discretionary income to splurge on clothing and recreational activities and do not necessarily have dependents or long term financial commitments to consider yet.

When considering the influence of age on consumers' complexity perceptions, findings revealed notable differences for purchasing a home, a car, choosing a holiday destination, purchasing an outfit for a special occasion as well as choosing a restaurant for family night out, which differed from product decisions that came to the fore during the gender investigation. This highlights the need for marketers' and retailers' cognisance of, and attention to the relevance of specific demographic influences when communicating product information in various media as well as the need for dissimilar approaches during consumer facilitation and personal purchase encounters. Table 4 highlights significant differences for certain purchase decisions, based on ANOVA.

\section{INSERT TABLE 4 HERE}


Education level: A consumer's ability to function in the market place, i.e. possession of the functional and symbolic knowledge that is required to make informed purchase decisions or to pursue avenues to do so when required, is strongly influenced by the individual's educational level (John, 1999). Findings presented in Table 5 confirm significant differences in consumers' perception of the level of complexity for certain purchase decisions across different education levels.

For higher educated consumers it apparently becomes more complex to purchase a home and a car, which represent the two most complex purchases compared to MHA. Both these purchases involve, amongst other types of risk, considerable social risk (Mandel, 2003; Dellaert et al., 2008; Hawkins and Mothersbaugh, 2010, p.533). There is a significant increase in the complexity of both purchase decisions (means) as education level increases ( $\mathrm{p} \leq$ 0.01).Literature proposes the contrary, stating that consumers with sufficient knowledge or experience in a specific product category might perceive less risk when purchasing that product (Grobe et al., 1999; Kim and Lennon, 2000; Jacobs and De Klerk, 2007) because prior experience increases cognitive ability and reduces uncertainty and perceived risk (Mandel, 2003; Dellaert et al., 2008). Various reasons could explain the findings of this study: lower educated people generally have lower incomes and do not necessarily have the same options that higher educated people with higher income consumers have when purchasing a home or a car. As explained by Dellaert et al (2008). lower educated consumers might also lack the cognitive ability to comprehend the implications of their purchase decisions (functional-, performance characteristics) and might subsequently not consider, or be bothered about all the functional and quality related issues. A follow-up study could investigate this contradiction.

Of all the purchase decisions investigated, grocery purchases seemed the least complex compared to MHA. For this product category there was a highly significant decrease in complexity with increase in education level $(\mathrm{p} \leq$ 0.01), which confirms extant literature (Viswanathan et al., 2005), that have noted the challenges associated with food and grocery purchases for lower educated, low income consumers. A lower education level results in lack of cognitive ability to decipher product information that would enable an informed choice that would ensure value for money purchase decisions (Wallendorf, 2001).

Higher educated consumers found it significantly less complex than higher educated individuals to purchase career wear $(\mathrm{p} \leq 0.05)$. Presumably the risk associated with the wrong or inappropriate choice (either performance-, functional- and/or financial risk) would be instrumental to explain this finding because career wear is not an 
essential purchase. Findings are supported by a study of Iacobucci (1992) which concluded that consumers find it more difficult to purchase tailored clothing than informal clothing such as jeans.

\section{INSERT TABLE 5 HERE}

Income: Income influences affordability and inevitably limits a consumer's exposure to- and experience with consumer goods and services, especially non-essentials and luxury products. Limited affordability is likely to increase the perceived complexity of certain purchase decisions (Wallendorf, 2001). Social affiliation becomes more important for consumers with higher incomes. Social risk and psychological risk therefore becomes a stronger influence for purchase decisions where social aspects and reference group norms are crucial to gain the approval of significant others (Oleson, 2004). On the other hand, lower income consumers are generally more concerned about value for money (Wallendorf, 2001; Robert et al., 2003) and wasting their money on products that do not meet their basic needs. Notable differences in perceived complexity across different income levels for certain purchase decisions as indicated in Table 6 resemble the findings for different age- and education levels.

Findings indicate that relative to the complexity associated with purchasing MHA, the complexity of the socalled least complex purchase decisions in this study, namely grocery purchases and choosing a restaurant for a family night out, was significantly higher for lower- than for higher income groups. Furthermore the complexity increased significantly with decrease in income (Groceries: $p \leq 0.01$; Restaurant: $p \leq 0.05$ ). Findings also suggest that it is significantly more complex for lower income consumers to have appliances repaired ( $\mathrm{p} \leq 0.05)$.A previous study that was done in the same geographic area (Erasmus et al., 2006) concluded that low income consumers may even opt to replace a faulty appliance because repair services cannot be paid for in instalments and because the success of the repair job is not necessarily guaranteed. Purchasing career wear, another of the less complex purchase decisions, was also significantly more complex for lower- than for higher income consumers $(\mathrm{p} \leq 0.05)$, which may be attributed to the challenge associated with affording clothing that would socially acceptable in a particular environment.

INSERT TABLE 6 HERE

Findings are summarised in Table 7

INSERT TABLE 7 HERE 


\section{Discussion and conclusions}

This study investigated the complexity of selected purchasing scenarios that households are confronted with from time to time in terms of a specific product, namely major household appliances as the reference point (anchoring product). Use of a reference point was meant to guide respondents to frame their complexity perceptions, i.e. to allow them to mentally compute the difficulty of each product decision relative to a product that the researchers assumed all would be accustomed with. The researchers acknowledge the influence of contextual influences, personal factors and decision styles in terms of consumers' perceptions and purchasing behaviour, however, this study intentionally aimed to divert attention solely to the products to construct a more simplistic complexity continuum to address a void in literature when different levels of product decisions are explained without substantiated evidence to support the examples that are used. The instructions in the questionnaire were therefore not presented in terms of specific scenarios, for example purchasing clothing at a sale, or choosing a family restaurant to celebrate mom's birthday. Thereby attention to contextual influences was reduced and it was assumed that the size of the sample would to some extent negate personal and contextual influences when respondents answered the questions.

Findings confirmed that purchase decisions can, in general, be distinguished along a continuum of complexity. Findings were fairly consistent across the demographic groups, which confirm that it is possible to group products in terms of perceived complexity. This categorisation should benefit retail and marketing in terms of the type and extent of information that should be communicated in media as well efforts to reduce consumers' risk perception and to encourage informed consumer decision-making. It became evident that the most expensive purchases that households ever make, namely purchasing a home and a car, which both involve longer term financial commitments, are perceived to be the most complex by all. Also on the more complex divide of the continuum are service related decisions such as insurance, medical cover and choosing a home security provider of which the post purchase implications are more difficult to foresee compared to tangible attribute based products. Findings of this study will also enhance the construct validity of future studies because researchers can now suitably identify product categories

for specific investigations, for example to investigate the influence of contextual influences, personal factors or decision styles on consumers' purchase behaviour. Findings of this study for example revealed that electronic goods 
such as a television set are perceived as considerably more complex that a cell phone, while off hand, one would have expected these two products to be highly similar.

Particularly noteworthy is the confirmation of significant differences among certain demographic groups in terms of the perceived complexity within product categories. This came to the fore in product categories that are perceived to be the most complex by all (namely purchasing a home and a car) as well as product categories that are perceived to be the least complex (namely purchasing groceries, choosing an outfit for a special occasion and purchasing career wear). This confirms the relevance of demographic information such as income and education level in market segmentation as well as for marketing managers who constantly have to perk up their competitiveness in the market place. Income level is probably relevant in terms of affordability and financial risk perception, which may require a review of the processes component of a company's marketing mix to attract or retain customers. Within product categories, the younger-, lower income- and lower educated consumers apparently perceive the purchase decision significantly more complex. This confirms the vulnerability of certain segments of the consumer society and the need for concerted effort to communicate with them in appropriate media and on a level that would enhance informed consumer decision-making. Distinct differences among level of education categories caution about the type of assistance that may be required in a retail environment that has become predominantly self service in nature in recent years.

Interestingly the findings of the gender comparison shifted the focus to product categories other than those elicited in the age-, income and level of education investigations. Purchase decisions that might still acclaim a stereotypical male orientated gender role, for example having appliances repaired, purchasing a computer and choosing a home security system, seem significantly more complex for females. Gender based literature postulate specific decision-making styles for men, namely that they tend to rely on, and to base their purchase decisions on a limited amount of information while females are inclined to get distracted by too much information that is not necessarily relevant. These findings are useful in terms of the appropriate media in which products should be advertised as well as the type of information that need to be included in marketing material. Findings of this study indicate that the evolution of gender roles in terms of certain household product decisions may be slower than anticipated. This could be explored in future research.

Findings therefore confirm the relevance of demographic characteristics in media communication and consumer facilitation as well as in research. Retailers and marketing managers should therefore be cognisant of the 
characteristics of their target markets and be very selective and cautious when identifying communication media. In a relationship orientated, highly competitive market a "one size fits all" approach is prone to fail. In an intricate market a better understanding of the challenges that are faced by vulnerable consumer groups - even when purchasing products that are generally perceived as routine, less complex activities, a more empathetic approach from a retail and marketing perspective would be to the benefit of all.

The study unfortunately had pertinent limitations. Although the list of products and services that were included in the research was carefully designed, the list could be extended, for example to include fine dining restaurants, a visit to a medical practitioner, and choosing a school for your child's education. Certain product categories can be refined to refer to specific products rather than product categories, for example distinguishing groceries in terms of perishables, non-perishables and toiletries; or to distinguish clothing purchases more specifically in terms formal, informal, under wear as an indication of visual significance. Future research can be done in terms of alternative reference points on the complexity continuum, for example to expand clothing categories in terms of those that have been established in this investigation. Findings can also be supported through evidence obtained in qualitative studies that allow opportunity to gain an in depth understanding of consumers' choices.

23 | P a g e 


\section{References}

Babin, J.B., Harris, E.G., 2011. CB4. South-Western Cengage Learning, Mason, Ohio.

Bauer, H.H., Sauer, N.E., Becker, C., 2006. Investigating the relationship between product involvement and consumer decision-making styles. Journal of Consumer Behaviour 5, 342-354.

Bettman, J.R., Luce, M.F., Payne, J.W., 1998. Constructive consumer choice processes. Journal of Consumer Research. 25, 187-217.

Brown, S.A., Venkatesh, V., 2005. Model of Adoption of Technology in Households: A Baseline Model Test and Extension. MIS Quarterly 29 (3), 399-426.

Cant, M., Brink, A., Brijball, S., 2006. Consumer Behaviour. Juta, Cape Town.

Chandrashekaran, R., Jagpal, H., 1995. Is there a Well-Defined Internal Reference Price. Advances in Consumer Research. 22, 230-235.

Chizinsky, P., 2010. Living room scale. Available from: <http://www.piotr.chizinski.com/index.php/project/lrs>(accessed on 11.4.2011).

City of Tshwane Metropolitan Municipality, 2008. Household Survey. Available from: <http://www.tshwane.gov.za/AboutTshwane> (accessed on 20.4. 2012).

Cowley, E., Mitchell, A.A., 2003. The moderating effect of product knowledge on the learning and organization of product information. Journal of Consumer Research 30 (1), 443-454.

Croson, R., Gneezy, U.,2009. Gender differences in preferences. Journal of Economic Literature 47 (2), 448474.

Dellaert, B.G.C., Arentze, T.A., Timmermans, H.J.P., 2008.Shopping context and consumers' mental representation of complex shopping trip decision problems. Journal of Retailing 84 (2), 219-232.

Dhar, R., 1997. Consumer Preference for a No-Choice Option. Journal of Consumer Research24 (2), 215-231.

Donoghue, S., De Klerk,H.M.,Ehlers, L., 2008. Consumers' perception of the functional and symbolic performance failure of major electrical household appliances. Journal of Family Ecology and Consumer Sciences $36,40-48$.

Doole, I., Lancaster, P., Lowe, R., 2005. Understanding and managing customers. Prentice Hall, Harlow. 
Erasmus, A.C., Makgopa, M.M., Kachale, M.G.,2006. Inexperienced consumers' judgment of the quality of major household appliances. Advances in Consumer Research 7, 648-658.

Grant, R., Clarke, R.J., Kyriazis, E., 2010. Research needs for assessing online value creation in complex consumer purchase process behavior. Journal of Retailing and Consumer Services 17 , 53-60.

Grobe, D., Douthitt, R., Zepeda, L., 1999. Consumer risk perception profiles regarding recombinant bovine growth hormone (rbGH). Journal of Consumer Affairs 33 (2), 254-275.

Grønhaug, K., Kleppe, I.A., Haukeda, W., 1987. Observation of a strategic household purchase decision. Psychology and Marketing 4 (3), 239-253.

Hawkins, D.I., Mothersbaugh, D.L., 2010. Consumer Behavior. Building Marketing Strategy.Mc Graw Hill, New York.

Henthorne, T.L., LaTour, M.S.,Hudson, T.W., 1997. Japanese couples' marital roles in stages of product purchase decision making. International Marketing Review 14 (1), 39-58.

Hoyer, D.W., MacInnis, D.J., Pieters, R., 2013. Consumer Behaviour, 6th edn. South-Western Cengage Learning, Mason, Ohio.

Iacobucci, D., 1992. An empirical examination of some basic tenets in services: goods-services continua. In: Swartz, T.A., Bowen, D.E., Brown, S.W. (Eds), Advances in Services Marketing and Management: Research and Practice 1. JAI Press, Greenwhich, Ct, pp. 23-52.

Jacobs, B., De Klerk, H.M., 2007. Understanding female consumers' risks perception for apparel purchasing on the Internet. Journal of Family Ecology and Consumer Sciences 35, 47-58.

Jobber, D., 2010. Principles and Practice of Marketing, 6th edn. McGraw-Hill, London.

John, D.H., 1999; Consumer socialization of children: A retrospective look at twenty-five years of research. Journal of Consumer Research 26,183-213.

Jordaan, Y., Prinsloo, M., 2004. Grasping service marketing, 2nd edn. Self published, South Africa.

Kardes, F.R., Cline, T.W.,Cronley, M.L.,2011. Consumer Behaviour Science and Practice, International edn. South-Western Cengage Learning, Australia.

Keh,H.T., Sun, J., 2008. The Complexities of Perceived Risk inCross-Cultural Services Marketing. Journal of International Marketing 16 ( 1), 120-146. 
Keller, K., Staelin, R., 1987. Effects of Quality and Quantity of Information on Decision and Effectiveness. Journal of Consumer Research 14, 200-213.

Kim, M., Lennon, S.J., 2000. Television Shopping for Apparel in the United States: Effects of Perceived Amount of Information on Perceived Risks and Purchase Intentions. Family and Consumer Sciences Research Journal28 (3), 301-330.

Koch, J., Einsend, M., Petermann, A., 2008. How complexity impacts path dependent decision-making: The mediating role of heuristics. Latin American Advances in Consumer Research2.Available from: <http://www.acrwebsite.org/search/view-conference-proceedings.aspx?Id=14117> (accessed on 30.4. 2012).

Lamb, C.W., Hair, J.F., McDaniel, C., Boshoff, C.,Terblanche, N.S., 2008. Marketing. Oxford University Press, New York.

Le Roux, N., Erasmus, A.C., 2011. Residents' reflection on tenure in security estates in South Africa. Journal for Family Ecology and Consumer Sciences39, 19-32.Available from: <http://www.ajol.info/index.php/jfecs/article/view/71599> (accessed on 12.8.2013).

Lindquist, J.D., Sirgy, M.J., 2006. Shopper, Buyer, and Consumer Behaviour: Theory, Marketing Applications, and Public Policy Implications, 3rd edn. Thomson, Mason, Ohio.

Mandl, M., Felfernig, A., Teppan, E., Schubert, M., 2011. Consumer decision making in knowledge-based recommendation. Journal of Intelligent Information Systems 37, 1-22.

Mandel, N., 2003. Shifting Selves and Decision Making: The Effects of Self-Construal Priming on Consumer Risk-Taking. Journal of Consumer Research30 (1), 30-40.

Meier-Pesti, K., Goetze. E., 2006. Masculinity and femininity as predictors of financial risk-taking: evidence from a priming study on gender salience. European Advances in Consumer Research, 7.

Nieftagodien, S., Van der Berg, S., 2007. Consumption patterns and the black middle class: The role of assets. Stellenbosch Economic Working Papers: 02/07\Department of Economics and The Bureau For Economic Research. University of Stellenbosch. Available from: <http://www.ekon.sun.ac.za/wpapers/2007/wp022007/wp-022007.pdf $>$ (accessed 3.2. 2012).

Oleson, M., 2004. Exploring the relationship between money attitudes and Maslow's hierarchy of needs. International Journal of Consumer Studies 28(1), 83-92.

Parumasur, S.B., Roberts-Lombard, M., 2012. Consumer Behaviour, 2nd edn. Juta, Cape Town. 
Peter, J.P., Olson, J.C., 2010. Consumer Behavior and Marketing Strategy, $9^{\text {th }}$ edn. McGraw Hill Irwin, New York.

Pérez-Cabañero, C.,2007. Perceived risk on goods and service purchases. EsicMarket129, 183-199.

Puto, C.P., 1987. The framing of buying decisions. Journal of Consumer Research. 14, 301-315.

Ratneshwar, S.,Warlop, L., Mick, D.G., Seeger, G., 1997. Benefit salience and consumers' selective attention to product features. International Journal of Research in Marketing 14, 245-259.

Robert, J.A., Manolis, C.,Tanner, J.F., 2003. Family Structure, materialism and compulsive buying: a reinquiry and extension. Journal of The Academy of Marketing Science 31 (3), 300-312.

Rowe, D., Puto, C.P., 1987. Do consumers' reference points affect their buying decisions. Journal of Consumer Research. 14, 188-192.

Sherry, J.F.,1983. Gift-Giving in Anthropological Perspective. Journal of Consumer Research10, 157-168.

Schiffman, L.G., Kanuk. L.L., 2010. Consumer behaviour, 10th edn. Prentice Hall, New Jersey.

Shao, W., Lye, A., Rundle-Thiele, S., 2009. Different strokes for different folks: A method to accommodate decision -making heterogeneity. Journal of Retailing and Consumer Services 16, 495-501.

Sheth, J.N., Newman, B.I., Gross, B.L., 1991. Why we buy what we buy: A theory of consumption values. Journal of Business Research. 22, 159-170.

Simcock, P., Sudbury, L., Wright, G., 2006. Age, perceived risk and satisfaction in consumer decision making: A review and extension. Journal of Marketing Management 22, 355-377.

Solomon, M.R., 2011. Consumer behaviour: Buying, having, being, 9th edn.Prentice Hall, New Jersey.

Sonnenberg, N.C., Erasmus, A.C.,Donoghue, S., 2011. Significance of environmental sustainability issues in consumers' choice of major household appliances in South Africa. International Journal of Consumer Studies 35, 153-163.

Sproles, G.B., Kendall, E.L., 1986. A methodology for profiling consumers' decision-making styles. Journal of Consumer Affairs. 20, 267-279.

Sproles, E.K., Sproles, J.B., 1990. Consumer Decision-Making Styles as a Function of Individual Learning Styles. Journal of Consumer Affairs 24 (1), 134-147.

Sridhar, G., 2007. Consumer involvement in product choice - a demographic analysis. Journal of Management March, 131-148. 
Swait, J., Adamowitcz, W., 2001. The Influence of Task Complexity on Consumer Choice: A Latent Class Model of Decision Strategy Switching. Journal of Consumer Research 28 (1), 135-148.

Swanepoel, C., 2012. Young households' allocation of resources for their homes' interiors. University of Pretoria. Master's Dissertation.

Tversky, A., Kahneman, D., 1991. Loss aversion in riskless Choice: A reference-dependent model. Quarterly Journal of Economics. 106, 1039-1061.

Ursic, M.L., Helgeson, J.G., 1990. The impact of choice phase and task complexity on consumer decision making. Journal of Business Reserach 21, 69-90.

Viswanathan, M., Gau, R., 2005. Functional illiteracy and nutrition education in United States: a research based approach to the development of nutritional education materials for functional illiterate consumer. Journal of Macromarketing25 (2), 187-201.

Wajda, T.A.,Hu, M., 2004. Gender differences in cognitive structure: preferred levels of taxonomic abstraction. Gender and Consumer Behavior 7, 1-27.

Wallendorf, M., 2001. Literally literacy.Journal of Consumer Research 27, 505-511.

Watson, L., Spence, M.T., 2007. Causes and consequences of emotions on consumer behaviour: A review and integrative cognitive appraisal theory. European Journal of Marketing 41 (5/6), 487-511.

Weber, E.U.,Blais, A.E., Betz, N.E., 2002. A Domain-specific Risk-attitude Scale:

Measuring Risk Perceptions and RiskBehaviors. Journal of Behavioral Decision Making 15, 263-290.

Weber, E.U., Hsee, C., 1998. Cross-cultural differences in risk perception, but cross-cultural similarities in attitudes towards perceived risk. Management Science 44 (9), 1205-1217.

Weber, E.U., Johnson, E.J., 2006. Constructing Preferences from Memory. Available at: <http://ssrn.com/abstract=1301075>(accessed 12.8.2013).

Wertenbroch, K., Dhar, R., 2000. Consumer choice between hedonic and utilitarian goods. Journal of Marketing Research. 37, 60-71.

Williams, D.J., Noyes, J.M., 2007. How does our perception of risk influence decision-making? Implications for the design of risk information. Theoretical Issues in Ergonomics Science 8, 1-35. 
Winer, R.S., 1986. A Reference Price Model of Brand Choice for Frequently Purchased Products. Journal of Consumer Research. 13, 250-256.

Yoon, S., Oh, H., Cho, J.Y., 2010. Understanding furniture design choices using a 3D virtual showroom. Journal of Interior Design35 (3),33-50. 
Table 1.

Mean complexity values for the listed products and services.

\begin{tabular}{|c|c|c|c|c|c|c|c|c|c|}
\hline \multirow{2}{*}{$\begin{array}{l}\text { Purchase decision that was } \\
\text { compared to the complexity } \\
\text { associated with MHA purchase }\end{array}$} & \multirow{2}{*}{$\mathrm{N}^{1}$} & \multirow{2}{*}{ Mean $^{1}$} & \multirow{2}{*}{ SD } & \multirow{2}{*}{$\mathrm{T}$} & \multirow{2}{*}{ df } & \multirow{2}{*}{$\begin{array}{c}\text { Sign (2 } \\
\text { way) }\end{array}$} & \multirow{2}{*}{$\begin{array}{c}\text { Mean } \\
\text { diff }\end{array}$} & \multicolumn{2}{|c|}{$\begin{array}{c}\text { Ranges for the } \\
\text { differences between } 2 \\
\text { values }(\mathrm{p} \leq 0.05)\end{array}$} \\
\hline & & & & & & & & Low & Top \\
\hline Groceries & 450 & -1.48 & 1.512 & -20.827 & 449 & 0.000 & -1.484 & -1.62 & -1.34 \\
\hline Restaurant for a family night out & 452 & -1.02 & 1.548 & -14.007 & 451 & 0.000 & -1.020 & -1.16 & -0.88 \\
\hline Career wear & 453 & -.74 & 1.485 & -10.665 & 452 & 0.000 & -0.744 & -0.88 & -0.61 \\
\hline Outfit for special occasion & 450 & -.50 & 1.581 & -6.708 & 449 & 0.000 & -0.500 & -0.65 & -0.35 \\
\hline Cell phone & 453 & -.28 & 1.509 & -3.924 & 452 & 0.000 & -0.278 & -0.42 & -0.14 \\
\hline Appliances repaired & 452 & -.21 & 1.392 & -3.277 & 451 & 0.001 & -0.215 & -0.34 & -0.09 \\
\hline Birthday gift for someone special & 452 & -.19 & 1.599 & -2.500 & 451 & 0.013 & -0.188 & -0.34 & -0.04 \\
\hline Holiday destination* & 455 & -.14 & 1.470 & -1.977 & 454 & 0.051 & -0.136 & -0.27 & 0.00 \\
\hline Electronic goods $*$ & 453 & .10 & 1.393 & 1.518 & 452 & 0.130 & 0.099 & -0.03 & 0.23 \\
\hline Furniture * & 456 & .12 & 1.556 & 1.715 & 455 & 0.087 & 0.125 & -0.02 & 0.27 \\
\hline Computer & 455 & .23 & 1.523 & 3.263 & 454 & 0.001 & 0.233 & 0.09 & 0.37 \\
\hline Home security provider & 452 & .34 & 1.602 & 4.464 & 451 & 0.000 & 0.336 & 0.19 & 0.48 \\
\hline Insurance & 450 & .69 & 1.603 & 9.175 & 449 & 0.000 & 0.693 & 0.54 & 0.84 \\
\hline Medical cover & 450 & .88 & 1.655 & 11.281 & 449 & 0.000 & 0.880 & 0.73 & 1.03 \\
\hline Car & 453 & 1.53 & 1.566 & 20.758 & 452 & 0.000 & 1.528 & 1.38 & 1.67 \\
\hline Home & 454 & 1.83 & 1.529 & 25.443 & 453 & 0.000 & 1.826 & 1.68 & 1.97 \\
\hline
\end{tabular}


Table 2

Summary of research findings

\begin{tabular}{|c|c|c|}
\hline Hypotheses & Finding & Evidence \\
\hline $\begin{array}{l}\text { H1: The more expensive a product } \\
\text { for example a home and a car, } \\
\text { the higher the complexity of the } \\
\text { purchase decision. }\end{array}$ & Supported & $\begin{array}{l}>80 \% \text { of the respondents regarded purchasing a home and } a \\
\text { car as much more complex than purchasing MHA. } \\
\text { Purchasing a home and a car: significantly more complex } \\
\text { than purchasing MHA }(\mathrm{p} \leq 0.05) \text {. }\end{array}$ \\
\hline $\begin{array}{l}\text { H2: Purchase decisions that } \\
\text { involve intangible characteristics } \\
\text { for example services are high in } \\
\text { complexity. }\end{array}$ & Supported & $\begin{array}{l}\text { Choosing a home security provider and medical cover: } \\
\text { significantly more complex than purchasing MHA ( } \mathrm{p}= \\
<0.05) \text {. }\end{array}$ \\
\hline $\begin{array}{l}\text { H3: Purchase decisions that are } \\
\text { made less frequently, for } \\
\text { example a home and a car, are } \\
\text { high in complexity. }\end{array}$ & Supported & $\begin{array}{l}>80 \% \text { of the respondents regarded purchasing a home and } a \\
\text { car as much more complex than purchasing MHA. } \\
\text { Purchasing a home and a car: significantly more complex } \\
\text { than purchasing MHA }(\mathrm{p} \leq 0.05) \text {. }\end{array}$ \\
\hline $\begin{array}{l}\text { H4: Purchase decisions with social } \\
\text { implications are high in } \\
\text { complexity. }\end{array}$ & $\begin{array}{l}\text { Supported for } \\
\text { a home and a } \\
\text { car. } \\
\text { Not supported } \\
\text { for the apparel } \\
\text { purchases }\end{array}$ & $\begin{array}{l}>80 \% \text { of the respondents regarded purchasing a home and } a \\
\text { car as much more complex than purchasing the anchoring } \\
\text { product. Purchasing a home and a car: significantly more } \\
\text { complex than purchasing the anchoring product ( } \mathrm{p} \leq 0.05 \text { ). } \\
\text { Both of the clothing purchases were regarded significantly } \\
\text { less complex ( } \leq 0.05 \text { ) compared to purchasing MHA. }\end{array}$ \\
\hline $\begin{array}{l}\text { H5: Purchase decisions that } \\
\text { involve an evaluation of } \\
\text { technical features are high in } \\
\text { complexity. }\end{array}$ & $\begin{array}{l}\text { Supported for } \\
\text { purchasing a } \\
\text { computer. } \\
\text { Not supported } \\
\text { for cell } \\
\text { phones. }\end{array}$ & $\begin{array}{l}\text { Purchasing a computer: significantly more complex than } \\
\text { purchasing MHA }(\mathrm{p} \leq 0.05) \text {. } \\
\text { Purchasing a cell phone: significantly less complex than } \\
\text { purchasing MHA ( } \mathrm{p} \leq 0.05) \text {. }\end{array}$ \\
\hline $\begin{array}{l}\text { H6: } \text { Routine purchases such as } \\
\text { grocery purchases are low in } \\
\text { complexity. }\end{array}$ & Supported & $\begin{array}{l}\text { Purchasing groceries: the least complex purchase decision } \\
\text { compared to MHA; }>70 \% \text { of the sample indicated that } \\
\text { purchasing groceries is always/mostly easier to purchase } \\
\text { than the anchoring product; significantly less complex than } \\
\text { MHA (p } \leq 0.05 \text { ). }\end{array}$ \\
\hline
\end{tabular}


Table 3

Significant differences exposed through independent random tests that compared the complexity of purchase decisions relative to purchasing MHA between the gender groups.

\begin{tabular}{|c|c|c|c|c|c|c|c|c|c|c|}
\hline \multirow{3}{*}{$\begin{array}{c}\text { Complexity of } \\
\text { the purchase } \\
\text { compared to } \\
\text { MHA }\end{array}$} & \multirow{3}{*}{\multicolumn{2}{|c|}{$\begin{array}{l}\text { Complexity values } \\
\text { (means) }\end{array}$}} & \multicolumn{3}{|c|}{ Levene-Test } & \multicolumn{5}{|c|}{ Test to compare if 2 means are the same } \\
\hline & & & & \multirow[t]{2}{*}{$\mathrm{F}$} & \multirow[t]{2}{*}{$\begin{array}{l}\text { Level } \\
\text { of } \\
\text { Sign }\end{array}$} & \multirow{2}{*}{$\begin{array}{l}\text { Sign } \\
\text { level } \\
(2 \\
\text { sides })\end{array}$} & \multirow[t]{2}{*}{$\begin{array}{l}\text { Mean } \\
\text { Diff }\end{array}$} & \multirow[t]{2}{*}{$\begin{array}{l}\text { Std error } \\
\text { of the dif }\end{array}$} & \multicolumn{2}{|c|}{$\begin{array}{c}\text { Ranges for the } \\
\text { difference between } \\
\text { values }(\mathrm{p} \leq 0.05)\end{array}$} \\
\hline & & & & & & & & & Lower & Top \\
\hline \multirow[t]{2}{*}{$\begin{array}{l}\text { Appliances } \\
\text { repaired }\end{array}$} & Males & -0.44 & $\begin{array}{l}\text { Variances } \\
\text { are equal }\end{array}$ & 0.017 & 0.895 & 0.026 & 0.321 & 0.144 & -0.604 & -0.039 \\
\hline & Females & -0.12 & $\begin{array}{l}\text { Variances } \\
\text { not equal }\end{array}$ & & & 0.023 & 0.321 & 0.14 & -0.598 & -0.045 \\
\hline \multirow{2}{*}{$\begin{array}{l}\text { Choosing a } \\
\text { birthday gift } \\
\text { for someone } \\
\text { special }\end{array}$} & Males & 0.12 & $\begin{array}{l}\text { Variances } \\
\text { are equal }\end{array}$ & 0.055 & 0.814 & 0.008 & 0.437 & 0.164 & 0.115 & 0.759 \\
\hline & Females & -0.32 & $\begin{array}{l}\text { Variances } \\
\text { not equal }\end{array}$ & & & 0.009 & 0.437 & 0.165 & 0.111 & 0.762 \\
\hline \multirow[t]{2}{*}{ Computer } & Males & -0.07 & $\begin{array}{l}\text { Variances } \\
\text { are equal }\end{array}$ & 0.273 & 0.602 & 0.007 & 0.425 & 0.156 & -0.731 & -0.118 \\
\hline & Females & 0.36 & $\begin{array}{l}\text { Variances } \\
\text { not equal }\end{array}$ & & & 0.006 & 0.425 & 0.155 & -0.73 & -0.12 \\
\hline \multirow[t]{2}{*}{$\begin{array}{l}\text { Home security } \\
\text { provider }\end{array}$} & Males & 0.05 & $\begin{array}{l}\text { Variances } \\
\text { are equal }\end{array}$ & 0.090 & 0.764 & 0.016 & $\begin{array}{r}- \\
0.398 \\
\end{array}$ & 0.165 & -0.723 & -0.074 \\
\hline & Females & 0.45 & $\begin{array}{l}\text { Variances } \\
\text { not equal }\end{array}$ & & & 0.017 & 0.398 & 0.166 & -0.072 & -0.072 \\
\hline
\end{tabular}

Table 4.

Purchase decisions that differed significantly in perceived complexity across the age groups (ANOVA).

\begin{tabular}{|c|c|c|c|c|c|c|c|c|c|}
\hline \multicolumn{4}{|c|}{ Complexity of the product compared to MHA } & & \multirow{2}{*}{$\begin{array}{l}\text { Square } \\
\text { sum }\end{array}$} & \multirow[t]{2}{*}{ df } & \multirow{2}{*}{$\begin{array}{l}\text { Middle of } \\
\text { the squares }\end{array}$} & \multirow[t]{2}{*}{$\mathrm{F}$} & \multirow{2}{*}{$\begin{array}{l}\text { Level } \\
\text { of sign }\end{array}$} \\
\hline $\begin{array}{l}\text { Purchase } \\
\text { Mean }\end{array}$ & Age (yrs) & $\mathrm{n}$ & & & & & & & \\
\hline \multirow[t]{3}{*}{ Home } & $\leq 29$ years & 138 & 2.19 & Between the groups & 31.145 & 2 & 15.573 & 6.831 & 0.001 \\
\hline & $>29$ to 49 & 197 & 1.77 & Within the groups & 1028.108 & 451 & 2.280 & & \\
\hline & $>49$ years & 119 & 1.50 & Overall & 1059.253 & 453 & & & \\
\hline \multirow[t]{3}{*}{ Car } & $\leq 29$ years & 138 & 1.75 & Between the groups & 29.011 & 2 & 14.506 & 6.045 & 0.003 \\
\hline & $>29$ to 49 & 197 & 1.62 & Within the groups & 1079.894 & 450 & 2.400 & & \\
\hline & $>49$ years & 118 & 1.11 & Overall & 1108.905 & 452 & & & \\
\hline \multirow{3}{*}{$\begin{array}{c}\text { Holiday } \\
\text { destination }\end{array}$} & $\leq 29$ years & 138 & -0.38 & Between the groups & 17.883 & 2 & 8.942 & 4.194 & 0.016 \\
\hline & $>29$ to 49 & 198 & 0.08 & Within the groups & 963.668 & 452 & 2.132 & & \\
\hline & $>49$ years & 119 & -0.20 & Overall & 981.552 & 454 & & & \\
\hline \multirow{3}{*}{$\begin{array}{l}\text { Outfit for } \\
\text { special } \\
\text { occasion }\end{array}$} & $\leq 29$ years & 139 & -0.81 & Between the groups & 20.715 & 2 & 10.357 & 4.202 & 0.016 \\
\hline & $>29$ to 49 & 196 & -0.32 & Within the groups & 1101.785 & 447 & 2.465 & & \\
\hline & $>49$ years & 115 & -0.43 & Overall & 1122.5 & 449 & & & \\
\hline \multirow{3}{*}{$\begin{array}{l}\text { Restaurant } \\
\text { for family } \\
\text { night out }\end{array}$} & $\leq 29$ years & 138 & -1.42 & Between the groups & 31.923 & 2 & 15.962 & 6.833 & 0.001 \\
\hline & $>29$ to 49 & 196 & -0.83 & Within the groups & 1048.898 & 449 & 2.336 & & \\
\hline & $>49$ years & 118 & -0.86 & Overall & 1080.821 & 451 & & & \\
\hline
\end{tabular}

*: Maximum $=+3 ;$ Minimum $=-3$ 
33 I P a g e 
Table 5.

Purchase decisions that differed significantly in terms of perceived complexity across groups with different levels of education (ANOVA).

\begin{tabular}{|c|c|c|c|c|c|c|c|c|c|}
\hline $\begin{array}{l}\text { Product } \\
\text { decision }\end{array}$ & Education level & $\mathrm{N}$ & Mean & & $\begin{array}{l}\text { Square } \\
\text { sum }\end{array}$ & $\mathrm{df}$ & $\begin{array}{l}\text { Middle } \\
\text { of the } \\
\text { squares }\end{array}$ & $\mathrm{F}$ & $\begin{array}{l}\text { Level of } \\
\text { sign }\end{array}$ \\
\hline \multirow[t]{6}{*}{ Home } & $<$ Grd 10 & 9 & 0.67 & \multirow{2}{*}{$\begin{array}{l}\text { Between } \\
\text { the groups }\end{array}$} & \multirow[t]{2}{*}{35.115} & \multirow[t]{2}{*}{4} & \multirow[t]{2}{*}{8.779} & \multirow[t]{6}{*}{3.858} & \multirow[t]{6}{*}{0.004} \\
\hline & Grde $10 / 11$ & 12 & 1.17 & & & & & & \\
\hline & Grd 12 & 113 & 1.54 & \multirow{2}{*}{$\begin{array}{l}\text { Within the } \\
\text { groups }\end{array}$} & \multirow[t]{2}{*}{1012.709} & \multirow[t]{2}{*}{445} & \multirow[t]{2}{*}{2.276} & & \\
\hline & $\begin{array}{r}\text { Grd 12+ } \\
\text { degree/dipl }\end{array}$ & 206 & 1.99 & & & & & & \\
\hline & Post graduate & 110 & 1.99 & \multirow[t]{2}{*}{ Overall } & \multirow[t]{2}{*}{1047.824} & \multirow[t]{2}{*}{449} & & & \\
\hline & Overall & 450 & 1.83 & & & & & & \\
\hline \multirow[t]{6}{*}{ Car } & $<$ Grd 10 & 9 & 0.78 & \multirow{2}{*}{$\begin{array}{l}\text { Between } \\
\text { the groups }\end{array}$} & \multirow[t]{2}{*}{39.968} & \multirow[t]{2}{*}{4} & \multirow[t]{2}{*}{9.992} & \multirow[t]{6}{*}{4.194} & \multirow[t]{6}{*}{0.002} \\
\hline & Grde $10 / 11$ & 12 & 0.5 & & & & & & \\
\hline & Grd 12 & 114 & 1.2 & \multirow{2}{*}{$\begin{array}{l}\text { Within the } \\
\text { groups }\end{array}$} & \multirow[t]{2}{*}{1057.934} & \multirow[t]{2}{*}{444} & \multirow[t]{2}{*}{2.383} & & \\
\hline & $\begin{array}{r}\text { Grd 12+ } \\
\text { degree/dipl }\end{array}$ & 206 & 1.71 & & & & & & \\
\hline & Post graduate & 108 & 1.69 & \multirow[t]{2}{*}{ Overall } & 1097.902 & 448 & & & \\
\hline & Overall & 449 & 1.53 & & & & & & \\
\hline & $<$ Grd 10 & 9 & 0.11 & Between & 28.775 & 4 & 7.194 & 2.914 & 0.021 \\
\hline Outfit for & Grde $10 / 11$ & 10 & 0.3 & the groups & & & & & \\
\hline $\begin{array}{l}\text { special } \\
\text { occasion }\end{array}$ & Grd 12 & 114 & -0.3 & Within the & 1090.975 & 442 & 2.468 & & \\
\hline & $\begin{array}{r}\text { Grd 12+ } \\
\text { degree/dipl }\end{array}$ & 205 & -0.48 & groups & & & & & \\
\hline & Post graduate & 109 & -0.86 & Overall & 1119.749 & 446 & & & \\
\hline & Overall & 447 & -0.5 & & & & & & \\
\hline & $<$ Grd 10 & 8 & 0 & Between & 22.991 & 4 & 5.748 & 2.439 & 0.046 \\
\hline Restaurant & Grde $10 / 11$ & 11 & -0.18 & the groups & & & & & \\
\hline $\begin{array}{l}\text { Ior ramily } \\
\text { night out }\end{array}$ & Grd 12 & 114 & -0.87 & Within the & 1043.829 & 443 & 2.356 & & \\
\hline & $\begin{array}{r}\text { Grd 12+ } \\
\text { degree/dipl }\end{array}$ & 207 & -1.10 & groups & & & & & \\
\hline & Post graduate & 108 & -1.19 & Overall & 1066.819 & 447 & & & \\
\hline & Overall & 448 & -1.02 & & & & & & \\
\hline & $<$ Grd 10 & 8 & 0 & Between & 36.837 & 4 & 9.209 & 4.125 & 0.003 \\
\hline Groceries & Grde $10 / 11$ & 11 & -0.73 & the groups & & & & & \\
\hline & Grd 12 & 112 & -1.29 & Within the & 986.752 & 442 & 2.232 & & \\
\hline & $\begin{array}{r}\text { Grd 12+ } \\
\text { degree/dipl }\end{array}$ & 207 & -1.54 & gr & & & & & \\
\hline & Post graduate & 109 & -1.75 & Overall & 1023.588 & 446 & & & \\
\hline & Overall & 447 & -1.48 & & & & & & \\
\hline & $<$ Grd 10 & 9 & -0.56 & Between & 32,532 & 4 & 8,133 & 3,803 & 0.005 \\
\hline Career & Grde $10 / 11$ & 11 & -0.09 & the groups & & & & & \\
\hline & Grd 12 & 114 & -0.48 & Within the & 349,500 & 444 & 2,139 & & \\
\hline & $\begin{array}{r}\text { Grd 12+ } \\
\text { degree/dipl }\end{array}$ & 205 & -0.70 & groups & & & & & \\
\hline & Post graduate & 110 & -1.16 & Overall & 982,031 & 448 & & & \\
\hline
\end{tabular}




Overall $\quad 449 \quad-0.74$

\section{Table 6}

Purchase decisions that differed significantly in terms of perceived complexity across the various income levels (ANOVA).

\begin{tabular}{|c|c|c|c|c|c|c|c|c|}
\hline & & $\mathrm{N}$ & Mean & & $\begin{array}{c}\text { Square } \\
\text { sum }\end{array}$ & $\mathrm{df}$ & $\begin{array}{c}\text { Middle of } \\
\text { the } \\
\text { squares }\end{array}$ & $\mathrm{F}$ \\
\hline \multirow[t]{6}{*}{ Groceries } & $<\mathrm{R} 5000$ & 37 & -0.46 & \multirow{2}{*}{$\begin{array}{l}\text { Between the } \\
\text { groups }\end{array}$} & \multirow[t]{2}{*}{62.651} & \multirow[t]{2}{*}{15.63} & \multirow[t]{6}{*}{7.22} & 0 \\
\hline & R5000 to $<\mathrm{R} 10000$ & 60 & -1.12 & & & & & \\
\hline & $\mathrm{R} 10000$ to $<\mathrm{R} 15000$ & 81 & -1.42 & \multirow{2}{*}{$\begin{array}{l}\text { Within the } \\
\text { groups }\end{array}$} & \multirow[t]{2}{*}{956.668} & \multirow[t]{2}{*}{2.169} & & \\
\hline & $\mathrm{R} 15000$ to $<\mathrm{R} 25000$ & 106 & -1.67 & & & & & \\
\hline & $\mathrm{R} 25000+$ & 162 & -1.75 & \multirow[t]{2}{*}{ Overall } & \multirow[t]{2}{*}{1019.318} & & & \\
\hline & Overall & 446 & -1.48 & & & & & \\
\hline \multirow{6}{*}{$\begin{array}{l}\text { Restaurant } \\
\text { family night }\end{array}$} & $<$ R5000 & 37 & -0.51 & \multirow{2}{*}{$\begin{array}{l}\text { Between the } \\
\text { groups }\end{array}$} & \multirow[t]{2}{*}{24.964} & \multirow[t]{2}{*}{6.241} & \multirow[t]{6}{*}{2.628} & \multirow[t]{6}{*}{0.034} \\
\hline & $\mathrm{R} 5000$ to $<\mathrm{R} 10000$ & 63 & -0.83 & & & & & \\
\hline & $\mathrm{R} 10000$ to $<\mathrm{R} 15000$ & 81 & -0.80 & \multirow{2}{*}{$\begin{array}{l}\text { Within the } \\
\text { groups }\end{array}$} & \multirow[t]{2}{*}{1049.854} & \multirow[t]{2}{*}{2.375} & & \\
\hline & $\mathrm{R} 15000$ to $<\mathrm{R} 25000$ & 105 & -1.25 & & & & & \\
\hline & R25000 + & 161 & -1.17 & \multirow[t]{2}{*}{ Overall } & \multirow[t]{2}{*}{1074.819} & & & \\
\hline & Overall & 447 & -1.02 & & & & & \\
\hline \multirow{6}{*}{$\begin{array}{c}\text { Appliances } \\
\text { repaired }\end{array}$} & $<$ R5000 & 36 & -0.11 & \multirow{2}{*}{$\begin{array}{l}\text { Between the } \\
\text { groups }\end{array}$} & \multirow[t]{2}{*}{19.076} & \multirow[t]{2}{*}{4.796} & \multirow[t]{6}{*}{2.504} & \multirow[t]{6}{*}{0.042} \\
\hline & R5000 to $<$ R10 000 & 63 & -0.62 & & & & & \\
\hline & $\mathrm{R} 10000$ to $<\mathrm{R} 15000$ & 81 & -0.38 & \multirow{2}{*}{$\begin{array}{l}\text { Within the } \\
\text { groups }\end{array}$} & \multirow[t]{2}{*}{843.779} & \multirow[t]{2}{*}{1.905} & & \\
\hline & $\mathrm{R} 15000$ to $<\mathrm{R} 25000$ & 107 & -0.96 & & & & & \\
\hline & $\mathrm{R} 25000+$ & 161 & -0.97 & \multirow[t]{2}{*}{ Overall } & \multirow[t]{2}{*}{862.855} & & & \\
\hline & Overall & 448 & $0-.74$ & & & & & \\
\hline Career wear & $<\mathrm{R} 5000$ & 38 & 0.08 & Between the & 39.236 & 9.809 & 4.573 & 0.001 \\
\hline & R5000 to $<$ R10 000 & 62 & -0.11 & orouns & & & & \\
\hline & R10000 to $<\mathrm{R} 15000$ & 79 & 0.09 & Within the & 950.244 & 2.145 & & \\
\hline & $\mathrm{R} 15000$ to $<\mathrm{R} 25000$ & 107 & -0.26 & & & & & \\
\hline & $\mathrm{R} 25000+$ & 162 & -0.43 & Overall & 989.48 & & & \\
\hline & Overall & 448 & -0.21 & & & & & \\
\hline
\end{tabular}


Table 7.

Summary of research findings

\begin{tabular}{|c|c|c|}
\hline Hypotheses & Finding & Evidence \\
\hline $\begin{array}{l}\text { H1: The more expensive a product } \\
\text { for example a home and a car, } \\
\text { the higher the complexity of the } \\
\text { purchase decision. }\end{array}$ & Supported & $\begin{array}{l}>80 \% \text { of the respondents regarded purchasing a home and } a \\
\text { car as much more complex than purchasing MHA. } \\
\text { Purchasing a home and a car: significantly more complex } \\
\text { than purchasing MHA }(\mathrm{p} \leq 0.05) \text {. }\end{array}$ \\
\hline $\begin{array}{l}\text { H2: Purchase decisions that } \\
\text { involve intangible characteristics } \\
\text { for example services are high in } \\
\text { complexity. }\end{array}$ & Supported & $\begin{array}{l}\text { Choosing a home security provider and medical cover: } \\
\text { significantly more complex than purchasing MHA }(\mathrm{p}= \\
<0.05) \text {. }\end{array}$ \\
\hline $\begin{array}{l}\text { H3: Purchase decisions that are } \\
\text { made less frequently, for } \\
\text { example a home and a car, are } \\
\text { high in complexity. }\end{array}$ & Supported & $\begin{array}{l}>80 \% \text { of the respondents regarded purchasing a home and } a \\
\text { car as much more complex than purchasing MHA. } \\
\text { Purchasing a home and a car: significantly more complex } \\
\text { than purchasing MHA }(\mathrm{p} \leq 0.05) \text {. }\end{array}$ \\
\hline $\begin{array}{l}\text { H4: Purchase decisions with social } \\
\text { implications are high in } \\
\text { complexity. }\end{array}$ & $\begin{array}{l}\text { Supported for } \\
\text { a home and a } \\
\text { car. } \\
\text { Not supported } \\
\text { for the apparel } \\
\text { purchases }\end{array}$ & $\begin{array}{l}>80 \% \text { of the respondents regarded purchasing a home and } a \\
\text { car as much more complex than purchasing the anchoring } \\
\text { product. Purchasing a home and a car: significantly more } \\
\text { complex than purchasing the anchoring product }(\mathrm{p} \leq 0.05) \text {. } \\
\text { Both of the clothing purchases were regarded significantly } \\
\text { less complex (p } \leq 0.05 \text { ) compared to purchasing MHA. }\end{array}$ \\
\hline $\begin{array}{l}\text { H5: Purchase decisions that } \\
\text { involve an evaluation of } \\
\text { technical features are high in } \\
\text { complexity. }\end{array}$ & $\begin{array}{l}\text { Supported for } \\
\text { purchasing a } \\
\text { computer. } \\
\text { Not supported } \\
\text { for cell } \\
\text { phones. }\end{array}$ & $\begin{array}{l}\text { Purchasing a computer: significantly more complex than } \\
\text { purchasing MHA }(\mathrm{p} \leq 0.05) \text {. } \\
\text { Purchasing a cell phone: significantly less complex than } \\
\text { purchasing MHA ( } \mathrm{p} \leq 0.05) \text {. }\end{array}$ \\
\hline $\begin{array}{l}\text { H6: Routine purchases such as } \\
\text { grocery purchases are low in } \\
\text { complexity. }\end{array}$ & Supported & $\begin{array}{l}\text { Purchasing groceries: the least complex purchase decision } \\
\text { compared to MHA; }>70 \% \text { of the sample indicated that } \\
\text { purchasing groceries is always/mostly easier to purchase } \\
\text { than the anchoring product; significantly less complex than } \\
\text { MHA ( } \leq \leq 0.05 \text { ). }\end{array}$ \\
\hline $\begin{array}{l}\text { H7: When doing a gender } \\
\text { comparison of consumers } \\
\text { perception of the complexity of } \\
\text { purchase decisions: } \\
\text { H7.1: The complexity of purchase } \\
\text { decisions that are attribute-based } \\
\text { is higher for females compared to } \\
\text { males. } \\
\text { H7.2: The complexity of purchase } \\
\text { decisions that lack tangible } \\
\text { requisites is significantly higher for } \\
\text { males compared to females. }\end{array}$ & Supported & $\begin{array}{l}\text { H7.1: Compared to males, females' perception of computer } \\
\text { purchase is significantly higher }(\mathrm{p} \leq 0.01) \text {. } \\
\text { H7.2: Compared to females' perception of a birthday gift } \\
\text { purchase issignificantly higher }(\mathrm{p} \leq 0.01)\end{array}$ \\
\hline $\begin{array}{l}\text { H8: The complexity of purchase } \\
\text { decisions is higher for consumers } \\
\text { with limited experience, such as: } \\
\text { H8.1 younger consumers }\end{array}$ & & $\begin{array}{l}\text { H8.1 Although significantly more complex than MHA for } \\
\text { all, the complexity of a car purchase decreased progressively } \\
\text { and significantly for older consumers }(\mathrm{p} \leq 0.01 ; \beta=-0.170 \text {; } \\
\mathrm{R}^{2}=0.02 \text { ). Regression analysis also confirmed a significant } \\
\text { inverse relationship between age and the complexity value }\end{array}$ \\
\hline
\end{tabular}




\begin{tabular}{|c|c|c|}
\hline $\begin{array}{l}\text { H8. } 2 \text { consumers who are } \\
\text { unfamiliar with a specific } \\
\text { purchasing task }\end{array}$ & $\begin{array}{l}\text { Supported } \\
\text { Supported }\end{array}$ & $\begin{array}{l}\text { ( } \mathrm{p} \leq 0,000) \text { for a home purchase decision, i.e. the older the } \\
\text { consumer, the lower the perceived complexity or vice versa } \\
\left(\beta=-0,170 ; \mathrm{R}^{2}=0.027\right) \text {. } \\
\text { H8.2 Females who are probably less familiar with the task, } \\
\text { perceived it significantly more complex to choose a repair } \\
\text { service compared to men }(\mathrm{p} \leq 0.05) \text {. }\end{array}$ \\
\hline $\begin{array}{l}\text { H9: The complexity associated with } \\
\text { purchase decisions is higher for } \\
\text { consumers with lower education } \\
\text { levels. }\end{array}$ & $\begin{array}{l}\text { Not supported } \\
\text { for products } \\
\text { high in } \\
\text { complexity. } \\
\text { Supported for } \\
\text { products low } \\
\text { in complexity }\end{array}$ & $\begin{array}{l}\text { Higher educated consumers find it significantly more } \\
\text { complex to purchase a home and a } \operatorname{car}(\mathrm{p} \leq 0.01) \text {. } \\
\text { Higher educated consumers find it significantly less } \\
\text { complex to purchase groceries }(\mathrm{p} \leq 0.01) \text {. }\end{array}$ \\
\hline $\begin{array}{l}\text { H10: The complexity associated } \\
\text { with purchase decisions is higher } \\
\text { for consumers with lower income } \\
\text { levels. }\end{array}$ & Supported & $\begin{array}{l}\text { Even for the least complex purchase decisions, i.e. namely } \\
\text { grocery purchases and choosing a restaurant for a family } \\
\text { night out, the complexity associated with the purchase was } \\
\text { significantly higher for lower- than for higher income } \\
\text { groups, and the complexity increased significantly with } \\
\text { decrease in income (Groceries: } \mathrm{p} \leq 0.01 \text {; Restaurant: } \mathrm{p} \leq \\
0.05 \text { ). } \\
\text { It was also significantly more complex for lower income } \\
\text { consumers to have appliances repaired ( } \mathrm{p} \leq 0.05 \text { ). }\end{array}$ \\
\hline
\end{tabular}

